\title{
The Sources of Political Normativity: the Case for Instrumental and Epistemic Normativity in Political Realism
}

\author{
Carlo Burelli ${ }^{1}$ (D) Chiara Destri $^{2}$
}

Accepted: 1 October 2021 / Published online: 27 October 2021

(c) The Author(s), under exclusive licence to Springer Nature B.V. 2021

\begin{abstract}
This article argues that political realists have at least two strategies to provide distinctively political normative judgements that have nothing to do with morality. The first ground is instrumental normativity, which states that if we believe that something is a necessary means to a goal we have, we have a reason to do it. In politics, certain means are required by any ends we may intend to pursue. The second ground is epistemic normativity, stating that if something is (empirically) true, this gives us a reason to believe it. In politics, there are certain empirical regularities that ought to be acknowledged for what they are. Both sources are flawed. Instrumental normativity only requires coherence between attitudes and beliefs, and one can hang on to false beliefs to preserve attitudes incompatible with reality. I may desire to eschew power relations, and accordingly I may imagine politics to be like a camping trip. Epistemic normativity, on the other hand, operates critically, striking down existing normative claims. It shows us that politics is nothing like a camping trip, but it doesn't tell us what we should do about it (beyond abandoning some false beliefs). We conclude by showing that if the two are taken together, they remedy each other's flaws.
\end{abstract}

Keywords Normativity $\cdot$ Sources of Normativity $\cdot$ Political Realism $\cdot$ Epistemic Normativity · Instrumental Normativity · Reasons

Dr. Carlo Burelli

carlo.burelli@edu.unige.it

Dr. Chiara Destri

chiara.destri@sciencespo.fr

University of Genova, Genova, Italy

Sciences Po, Paris, France 


\section{Introduction}

Political realism always presents a puzzle. On one side, it downplays the importance of morality in politics. On the other, realism is not lacking in prescriptions. Machiavelli's influential Prince ([1532] 2010), for example, is meant to be a guide for how princes ought to behave, not a mere description of how princes actually behave. This is what made it scandalous: everybody knew that Renaissance princes acted immorally, but only Machiavelli dared to argue that they were justified in doing so (McCormick 2020, 3).

It is possible to read realism as critical only of a specific understanding of morality. This interpretation could be accurate for some classic authors. Machiavelli rejected the popular view of morality based on Christian values and instead revived the pagan virtues of Rome (Berlin 2013). In modern times, Weber ([1919] 2004) presented a form of realism that championed a consequentialist view of morality (the 'ethics of responsibility') as a better political alternative than deontological approaches (the 'ethics of conviction').

Contemporary realists do not merely question the deontological flavour of current political theory, but criticise the very role of morality in politics. Bernard Williams (1973), for example, is equally critical of consequentialist approaches to politics, such as utilitarianism. According to him, both utilitarian philosophers and deontological theorists are guilty of the same mistake: they start from an ideal theory of what individuals owe to each other and then apply this deductively to political problems. Realists name this approach 'moralism' (Williams 2005) or the 'ethics-first view' (Geuss 2008), and they argue that it mistakenly understands political theory as applied morality. A common example of moralism is Robert Nozick (1974), who explicitly assumes that

'moral philosophy sets the background for, and the boundaries of, political philosophy. What persons may and may not do to one another limits what they may do through the apparatus of a state, or do to establish such an apparatus' (6).

But can realists also advocate alternative normative recommendations? Many realists attempt to do so ${ }^{1}$ offering defences of equality (Jubb 2015), liberty (Hall 2015), and democracy (Beetz and Rossi 2017). Yet critical voices lament the lack of ambitiousness in realist normative theories: their approach allegedly leads to 'low bar conclusions' (Erman and Möller 2018). More radically, critics deem realism an entirely descriptive enterprise that ought to reject even small demands that deviate from what is actually being done (Estlund 2014, 123). In other words, realism stands accused of being either merely descriptive, and thus unable to deliver normative criticism, or straightforwardly inconsistent, having to rely in some way on a moral source of normative judgements that it rejects.

To provide normative conclusions, realists often refer to a 'distinctively political normativity' (Jubb 2019). The expression is itself ambiguous. Under a strong interpretation, the claim states that there is a distinctively political source of normativity that comes from within the political sphere. This normative source is distinct from the conventional moral grounding of much contemporary philosophy but also different from other consolidated sources of normativity, such as epistemic, prudential, and aesthetic normativity.

Under a weaker interpretation, realists might mean that there are distinctively political normative judgements - that is, specific ought-to statements that apply to political actors, or specific standards that political institutions ought to satisfy. As virtually all forms of political

${ }^{1}$ Though some reject this prescriptive ambition in favour of an interpretative role (see Horton 2017). 
theorising pass this desideratum (including Rawls's insistence on 'political justification'), something more is required to make the weaker claim distinctive of realism. This additional qualification is that the normative source invoked is not itself moral. In other words, there are distinctively political normative judgements that have nothing to do with morality.

Critics of realism contest both interpretations. To the extent that realists want to offer any normative guidance at all, they need to acknowledge that 'political justification is irreducibly moral' (Erman and Möller 2015a, 1) and has 'its ineliminable roots in morality' (Leader Maynard and Worsnip 2018, 787).

The aim of this article is to defend the weaker interpretation of the distinctiveness of political normativity: realists can be normative without relying on moral values. The article isolates and assesses the viability of two strategies used by realists to vindicate a nonmoral normativity fit for the political sphere: instrumental and epistemic normativity. While these are invoked in realist writings, they are rarely systematically scrutinised. By appealing to these two normative sources and by providing a conception of politics as a distinctive sphere of human activity, realists can offer political prescriptions that are not moral in character. Importantly, we do not advocate any substantive realist positions; rather, we aim to show how realism can consistently defend its metaethical claim of a distinctive political normativity.

The article unfolds as follows. After introducing the realist focus on politics (2), we dedicate the next two sections to instrumental (3) and epistemic (4) normativity. Section 5 argues that when these two are taken together, they can ground distinctively political normative judgements.

The upshot of the argument, teased out in the conclusion, is that morality is not all that ought to matter in politics. It is not just the case that political actors factually disregard moral obligations for example, using lies or coercion; there is a sense in which they sometime have reasons to do so.

\section{Real Politics for Realists}

Political realism revolves around the claim that political philosophers should start theorising from an accurate understanding of 'real politics' (Geuss 2008). Indeed, realists commonly lament that liberal philosophy betrays a desire to 'displace' (Honig 1993), 'reject' (Newey 2000) or 'evade' (Galston 2010) politics. The methodological recommendation that realists put forward ('Look at real politics!') presumes that there is a sphere of human activity identifiable as politics and that understanding its features is crucial in formulating action-guiding prescriptions. Importantly, if realism is meant to be distinct from nonideal theory, it cannot simply be concerned with 'the role of feasibility constraints in normative theorising' (Rossi 2016, 410-11) - that is, outlining the conditions for implementing moral values in the real world. Rather, realists propose 'alternative accounts of the nature, content and limits of politics' (Sleat 2014b, 35) that directly impact desirability.

Yet this intent raises two worries: First, it is not obvious that there is such a thing as real politics. This preliminary problem will be dealt with in this section. Second, the distinctively realist sense in which an appropriate account of politics plays a genuinely normative role is also unclear. This more serious objection will be addressed in the rest of the article. 
So, what is politics for realists? Realists highlight empirical regularities that apply to all political contexts - that is, viewing politics as 'the sphere of contest between human wills competing for power or influence to determine what decision is taken' (Sleat 2013, 57). Politics for realists entails two features. First, it involves the idea that some binding collective decisions need to be taken. Social coordination is not spontaneous, but it is a precious, if fragile, achievement that needs to be constantly maintained (Waldron 1999). Second, realists emphasise that individuals regularly and harshly disagree about such binding collective decisions, so much so that at least some of them would be willing to resort to violence to have their way, absent a centralised political authority (Burelli 2019). This general view of politics underlies important features of political life that various realists place at the centre of their reflections. Examples are many: authoritative coercion (Sleat 2014a), strategic reasoning (Schmidtz 2016), factual considerations (Rossi 2019), radical pluralism (Newey 1997), interests (Philp 2010).

Our goal here is not to defend a specific account of politics. Such an argument would take its own article ${ }^{2}$ because, while all realists share a common theme, they emphasise different aspects. Rather, our claim is that whatever the correct account of politics turns out to be, it can be used to supply distinctively political judgements which are nonmoral in character. Before we do that, it is important to dismiss the first worry concerning the possibility of identifying something like a political sphere. This worry consists of two general methodological objections.

The first doubt is that tracking general empirical regularities would yield an empty set, as contexts are too variable. Indeed, realism is often presented - and sometimes even presents itself — as sceptical of all universalist claims (Erman and Möller 2018, 536). Geuss (2008) argues that 'detached general statements. . have clear meaning at all only relative to their specific context' (14). For example, the human need for food tells us nothing without specifying what kinds of things humans understand to be food, how food is produced, and the like. And yet, while it is true that the need for food might tell us little without any context, we would not understand the importance of contextual forms of food production without assuming some universal need for food. ${ }^{3}$ Thus, it is important to keep in mind that realism is not necessarily hostile to abstraction. As Sleat $(2014 \mathrm{~b}, 4)$ famously points out, Hobbes is more realist than Locke, despite operating at a higher level of abstraction. Thus, we should interpret realists as taking the universal features and their contextual instantiations as practically inseparable. For example, Williams (2005) conceives of politics as 'the securing of order, protection, safety, trust, and the conditions of cooperation' (3). This feature is universal, being required literally 'all the time', and yet its answer is also always contextual, depending on 'historical circumstances' (3).

The second objection to realism's emphasis on politics is that politics is too open-ended to pin down its general empirical regularities. Politics is essentially contested, and both its goals and constraints are to be determined through politics itself (Erman and Möller 2021, 9). Due to such unsolvable conceptual disagreement, a definite sphere of politics can be neither meaningfully identified nor unequivocally described. If realism's politics has no objective basis, it cannot be invoked to surreptitiously 'define out' of political theory

\footnotetext{
${ }^{2}$ In fact, one of us tackled this question elsewhere (Burelli 2019).

${ }^{3}$ Correctly separating contingent from universal features of politics is a fundamental challenge for realism (Erman and Möller 2018, 531) but cannot be addressed here. Realists are aware of the risk of ideological universalisations (Freeden 2012; Prinz and Rossi 2017, 8).
} 
moralist approaches (Estlund 2014, 131; Erman and Möller 2018, 532). However, while some disagreement about a complex sphere of human behaviour such as politics is certainly to be expected, definitions of politics are not entirely arbitrary. First, the fact that we disagree about these definitions certainly does not entail that there is no such a thing as politics. Philosophers also disagree about what justice is and where it applies: so-called 'circumstances of justice' (Rawls 1971, 109-12) are no less contested than 'circumstances of politics' (Waldron 1999, 3), as communitarians have shown (for example, Sandel 1998, 35). Second, some remarkable similarities are ubiquitous in very different political contexts, as previously suggested. Very general traits like disagreement, coercion, strategy, order, and authority are remarkably consistent across very different geographical and historical contexts, although they may be differently instantiated. Third, a consolidated discipline like political science would lose its specific object of inquiry if there was nothing distinct about politics. In fact, the question "What is politics?" prompted an important theoretical debate in political science (see Bartolini 2018). ${ }^{4}$

These two objections are not too serious. Indeed, critics of realism need not reject the importance of an accurate description of politics. That different domains of human life affect the balance of our rights and duties, and the moral permissibility of individual actions, is hardly contestable and rarely contested. As Erman and Möller (2015b), first, and Leader Maynard and Worsnip (2018), later, have pointed out, virtually all theorists agree that context affects normative prescriptions. Some critics of realism even explicitly acknowledge the existence of 'empirically constitutive political realities [...] that are systematically consequential in their normative implications' (Leader Maynard 2021, 1). The object of disagreement is rather the source of these prescriptions, which, contra what realists claim, remains moral in character. To give an example, becoming a professor generates new obligations and may plausibly make certain otherwise morally problematic actions (for example, ranking people's skills) morally permissible, even required. However, critics continue, this does not mean that professorship grounds new obligations irrespective of morality; rather, it is a context of ethics with its own peculiar moral rules.

In the next two sections, we respond to this powerful objection by suggesting that through instrumental and epistemic normativity, realists can channel their account of politics to yield distinctively political judgements even without relying on morality.

\section{Instrumental Normativity}

The first potential source of nonmoral normativity is instrumental. Very briefly, instrumental normativity conveys the idea that "whoever wills the end also wills (insofar as reason has decisive influence on his action) the indispensably necessary means to it that are within his power' (Kant 1998, 4:417). Kant's hypothetical imperative is the most notable instantiation of instrumental normativity, which, he thought, needed 'no special discussion' (4:417). The idea behind instrumental normativity is that we have reasons to take what we believe are necessary means for our goals: if we believe that publishing papers is necessary for becom-

\footnotetext{
${ }^{4}$ One may reply that the existence of a scientific discipline is not conclusive evidence in favour of the existence of its object of inquiry, as was the case with astrology. However, denying the epistemic credentials of political science seems a high cost to pay just to reject political realism.
} 
ing a university professor, and we want to become professors, we at least have a reason to (try to) get published. ${ }^{5}$

Realists' accounts of politics can be coupled with instrumental normativity to provide nonmoral normative judgements that apply both to individual actors and institutions. The previously introduced regularities of politics impact individual action in various ways, by dictating certain means as necessary and prohibiting others as detrimental to achieving our objectives in the political arena. Those actors who categorically refuse to adopt the required means are committing a mistake, regardless of their aims. Machiavelli's Prince is a paramount example: his advice was equally useful to malevolent and benevolent princes because any prince would benefit from using cunning and force ([1532] 2010,69). Similarly, this form of reasoning fits nicely with the long-lasting debates about dirty hands in politics (Walzer 2004; Bellamy 2010) and about the specific nonmoral virtues that political actors must display - for example, the abilities to get things done, to be strategic, to reach compromises, to win elections (Philp 2010). These are judgements about what individuals ought to do whatever their aims are - that is, regardless of whether individuals ought to have such aims.

Furthermore, instrumental normativity is also relevant at the collective level when we assess institutional desirability. For example, modus vivendi theorists observe that since conflict is an inherent feature of politics, political institutions' capacity to maintain peace is a more pressing concern than their capacity for realising justice (Horton 2010). The reason why people should seek peace is not that this is a collective end that outweighs their personal ends but that peace is required for any other personal end one may have. This indeed gives you a reason to consider other people's interests but this reason is instrumental in kind: it is in your own interest to do so to avoid violent conflicts.

Critics of realism do not necessarily deny the role of instrumental normativity, but they view it only as an instantiation of the so-called 'transmission principle' (Kiesewetter 2015). As Leader Maynard and Worsnip (2018) observe, 'Instrumental normativity is primarily a matter of the transmission of reasons, so to speak, from ends to means rather than of the creation of reasons ex nihilo' (779) and therefore only applies if individuals already have a moral reason to act in a certain way. Even those clearly nonmoral skills that are instrumentally required in politics are only valuable if deployed in defence of morally warranted aims. Advancing human rights or promoting equality may indeed require the exercise of nonmoral skills, but the reason to utilise those skills depends on a prior moral reason to pursue those aims, critics argue.

To answer this objection, let us first be clear on its interpretation. A stronger reading denies the existence of nonmoral reasons for action: the politician who wants power for power's sake lacks a morally justified agenda and hence has no reason to display political virtues. This interpretation is implausibly strong. Indeed, there are other normative reasons based on desire or self-interest (Schroeder 2007; Crisp 2018). If one has a prudential reason to become a professor, one also has an instrumental reason to publish, and neither is moral in kind. Similarly, an activist may have a morally neutral agenda, such as building a local stadium, and according to realism she should deploy certain nonmoral skills to pursue it.

A more charitable reading of this objection is that other normative reasons exist, but they are overruled by moral ones. Leader Maynard and Worsnip (2018) acknowledge the existence of "epistemic normativity, prudential normativity, "aim-given" normativity, and aesthetic normativity' (756). We should then understand them as asserting (1) that the nor-

\footnotetext{
${ }^{5}$ Whether instrumental rationality gives rise to 'oughts' or simply to 'a reason' is debated (Schroeder 2004).
} 
mative force of reasons for means derives from the normative force of reasons for ends; and (2) that moral reasons trump nonmoral ones. Hence, if prior reasons are prudential, for instance, the resulting prescription is prudential, while if prior reasons are moral, the resulting prescription is moral, even though it prescribes nonmoral skills (779). Additionally, if there is a conflict between prudential and moral reasons, the former must give way. If one has a reason to go to an academic job interview but encounters a drowning child, one's prudential reason must give way to the moral reason. In response, realists can retreat by limiting their political prescriptions to cases where nonmoral aims are morally permissible (though not justified; recall the stadium case), but this significantly weakens realism's bite.

Realists have another option though. ${ }^{6}$ The transmission principle only works if there is a prior reason: it cannot create reasons ex nihilo. By contrast, realists can appeal to the instrumental principle, which states that 'one should take the necessary means to whatever ends one intends to bring about' (Setiya 2007, 652). What is at stake in this case is the normativity of instrumental rationality - that is, the idea that the requirements of rationality are normative. Instrumental rationality is viewed as a matter of coherence between attitudes, such as beliefs and intentions, independently from the situation in which an agent finds herself and independently from her reasons for action (Kolodny 2005, 509). If we (a) intend to become a professor, (b) believe that publishing papers is necessary to become a professor, but (c) do not intend to publish, we are being irrational in the sense that our intentions and beliefs are incoherent. Importantly, this is true regardless of whether we have normative reasons to become professors (which would be required by the transmission principle). Perhaps if the reason for our professional aspirations is that we are full-blown narcissists, we should not become professors after all. And yet, the fact that we intend to become professors, believe that publishing is necessary, and refuse to publish makes us irrational in a special way. Instrumental rationality concerns all those cases in which our intentions and beliefs are not consistent with each other, even when our intentions are not supported by reasons.

While it has been traditionally taken for granted, the normative status of instrumental rationality is nowadays contested in metaethics (Raz 2005; Kolodny 2005; Broome 2005; Setiya 2007). Nonetheless, others have defended the view that instrumental rationality is normative (Beardman 2007; Southwood 2008; Schroeder 2009). What matters for realism is that there is a sense in which rationality makes demands on us. One outlook is that rationality is normative insofar as it gives us reasons to form a coherent set of intentions and beliefs given our first-personal standpoint (Southwood 2008, 27). If we intend to become professors, there are academic rules to follow which constrain our action independently from the reasons or goals that guide our intention. We may have moral reasons, such as educating students or contributing to scientific knowledge. But again, we may also do it out of narcissism. In all cases, it is possible to formulate prescriptions that are always necessary to be successful in academia - for example, that one should publish papers, participate in conferences,

\footnotetext{
${ }^{6}$ A second option for realists is denying that moral reasons always outweigh nonmoral ones. This strategy depends on the viability of a metaethical position (the nonsupremacy of moral reasons) - a debate that realism has so far avoided (Nye 2015) and that we do not have room to address here. This argument is not so outlandish as it might seem. To give a trivial example, let us assume that John promised Peter that he would do the house chores in the afternoon. John clearly has a moral reason to do the house chores. However, John discovers that his dream job interview has been rescheduled to that same afternoon. He has a prudential or desire-based reason to go to the interview. The two reasons conflict, and in this particular case it seems odd to say that John's moral reason to do as he promised outweighs his prudential reason to go to the interview. At the same time, it seems difficult to describe John's reason to go to the interview as moral in kind.
} 
and expand one's network. If these prescriptions are necessary, they at least provide us with instrumental reason to intend to publish papers or participate in conferences. Another view is that such prescriptions also provide us with reasons to act in these ways. While we cannot do justice to his view, Mark Schroeder convincingly shows that there are adequate subjective reasons for intenders to do what they intend ${ }^{7}$; hence, when aspiring professors have a reason to intend to publish, they also have at least a subjective reason to actually publish.

Naturally, this does not exhaust the list of prescriptions that one must satisfy to become a good professor: if good professorship requires that a professor care for her students, for instance, this list may well include moral requirements. Nor does it mean, as Leader Maynard and Worsnip $(2018,761)$ rightly note, that something like academic normativity exists. It does mean, though, that it is possible to offer normative judgements that result from a requirement of rational coherence between our intentions and beliefs. And it means that even if our intention is debatable (say we want to count all our garden's blades of grass), there are rational (say we take a magnifier) and irrational (say we start jumping around) ways to realise that intention.

If there is a sense in which instrumental rationality demands that we take what we believe are the necessary means to our ends, then realists can provide prescriptions that are normative without being moral. For example, critics of realism may sensibly offer moral recommendations that a politician must fulfil in order to be a good democratic representative (Dovi 2007). However, realists can legitimately emphasise that some of these prescriptions can (1) be justified independently from moral considerations, (2) hold even if the politician has mistaken objectives or self-interested aims, and (3) even conflict with other moral principles. Since a democratic politician needs to win elections, she must campaign in a certain way, and this may well bring her to forms of pandering and misleading rhetoric (Bagg and Tranvik 2019).

We should therefore understand realists as proposing to shift focus from the justification of political aims to the assessment of their required means. Since politics dictates certain means and excludes others, and since disagreement over the justification of political ends is never-ending, there is an important and legitimate place for political theorising around means and for conducting it in a way that is neutral across various ends that political actors may entertain. As Waltz points out, 'If it turns out that power is a necessary means, then power inevitably takes on some of the qualities of an end' $(2001,35)$. The account of politics illustrated in the previous section serves to provide prescriptions that apply both at the individual and collective levels. Individually, the fact that politics involves strategic actions gives content to a set of realist recommendations grounded in political agents' desire to affect policy outcomes. Collectively, realists identify conditions of politics the satisfaction of which takes priority over other goals simply because they are the prerequisite of any other goal.

Despite its potential, instrumental normativity is insufficient to carry the conclusions that realists care about. Since it only pertains to the internal coherence between attitudes and beliefs, it only works with the set of beliefs we already have and does not constitute a ground for individuals to change patently false beliefs (Kolodny 2005, 510). If we want to become professors but falsely believe that publishing papers undermines our career

\footnotetext{
${ }^{7}$ In Schroeder's words: 'Intenders have adequate subjective reason to do what they intend, and hence by a generalization of the transmission principle, adequate subjective reason to do what they believe to be necessary to what they intend' $(2009,239)$.
} 
chances, we are instrumentally rational if we do not publish. Similarly, if we believe that politics is like a camping trip, instrumental rationality would justify refusing to seek power.

Realism, on the other hand, places a strong emphasis on having an accurate view of politics. Politics is impervious to our attitudes: it has some objective features, and we should recognise these as true, regardless of our desires or false beliefs. Those who fail to do so are not necessarily morally blameworthy. They could simply be making an epistemic mistake: they just get politics wrong. Realism traditionally claims to have an epistemic edge over rival approaches. Machiavelli ([1532] 2010), for example, famously declared his intention to 'go directly to the effectual truth of the thing than to the imagination of it' (61). According to him, utopian philosophers were guilty of self-deception: they let their wishes interfere with a sober assessment of political reality. To fully account for the normativity of realist prescriptions, we need to introduce a second normative source.

\section{Epistemic Normativity}

Epistemic normativity has been widely acknowledged by epistemologists, who generally view truth as the pivotal normative goal of all cognitive inquiries. ${ }^{8}$ Truth (however conceived of) is the normative standard for whether we should believe a certain statement. Succinctly put,

'for any $\mathrm{p}$ one considers, one should believe that $\mathrm{p}$ iff $\mathrm{p}$ is true' (Nawar 2019, 2).

In an example:

Hannah should believe that snow is white iff 'Snow is white' is true.

What carries normative force is truth: the best reason for believing a statement is its truth value. Hannah might acquire the understandable but mistaken credence that snow is red because she was told so and she has never encountered snow. Yet Hannah should believe that snow is white because it is true that snow is white. While this kind of normativity seems plausible enough in such simple examples, one may wonder whether it fits the realist enterprise and whether it may be applied to a concept as complex as politics.

Early realists in the field of international relations spelled out the role of epistemic normativity unambiguously:

'Realism, believing as it does in the objectivity of the laws of politics, must also believe in the possibility of developing a rational theory that reflects, however imperfectly and one-sidedly, these objective laws. It believes also, then, in the possibility of distinguishing in politics between truth and opinion-between what is true objectively and rationally, supported by evidence and illuminated by reason, and what is only a subjective judgment, divorced from the facts as they are and informed by prejudice and wishful thinking' (Morgenthau 2005).

\footnotetext{
${ }^{8}$ Many epistemologists think that truth has normative value as the overriding cognitive objective. Perhaps the most explicit endorsement is given by Goldman $(1999,5 ; 2002,52)$, but the thesis is quite popular (for example, BonJour 1985, 9; Wedgwood 2002; David 2001, 2013; Piller 2009). For a criticism of the normative value of truth in epistemology, see Elgin (2004, 2017). For a recent response, see Nawar (2019).
} 
Their aim is to appropriately describe what is going on in the real world of international affairs, and, accordingly, they are guided by the overriding cognitive aim of truth.

Unfortunately, this aspect has not been systematically treated in realist political theory. Classical realists were far too pragmatic to waste time on such metaphysical considerations, while contemporary realists are often too wary of the epistemological difficulties associated with such a view. ${ }^{9}$ Nevertheless, there are many instances in which epistemic normativity, truth, facts, and empirical considerations are directly invoked, and no better example can be given of this than Williams.

Williams (2002) observes that even though modern culture indeed looks with scepticism at the 'absolute truths' of old, there is still a large interest in 'accuracy': 'a pervasive suspiciousness, a readiness against being fooled, an eagerness to see through appearances to the real structures and motives that lie behind them' (1).

Williams $(2002,41)$ imagines a simplified state of nature to explain why human beings value accuracy. ${ }^{10}$ In any environment, information is key to pinpoint both potential dangers and advantageous opportunities. Since having accurate beliefs about the world dramatically increases our individual ability to survive, there is strong selective pressure to cultivate the tendency to arrive at accurate beliefs. ${ }^{11}$

Such a notion of epistemic normativity is clearly different from moral normativity. A professor might be extremely proficient at distinguishing true and false statements about matters of fact. Yet she might fail on a moral level—for example, by treating her students disrespectfully. In this sense, epistemic normativity satisfies the realist desideratum of being independent from moral considerations.

But can epistemic normativity extend its bite from beliefs to actions? And how does it apply specifically to political situations? There are two popular realist strategies: through a conception of politics, and through ideology critique. ${ }^{12}$

As argued in the first section, many realists ground their views in an accurate conception of politics. One way to make sense of this claim is in epistemic terms. There are some empirical regularities, both contextual and universal, that concern political settings, and these ought to (epistemically) be accepted as true. In this sense, epistemic normativity is directly cashed out in political terms: political philosophers should start from an accurate description of 'how things really stand' (Geuss 2008, x) because 'there are certain facts about the actual nature of politics that any political philosophy must take as given' (Sleat

\footnotetext{
${ }_{9}^{9}$ One might object that truth is a too demanding epistemic ideal and one should settle for something weaker, like evidence or justification. Truth's demandingness, however, is mitigated if we subject it to an oughtimplies-can caveat. We are not required to know what we have no reasonable way of knowing, even if it is true. It would indeed be very strange to claim that Archimedes ought to have known that $\mathrm{E}=\mathrm{mc}^{2}$, simply because it is true. Yet it would also be odd to say that Hannah should not believe that snow is white, only because a usually reliable source told her that snow is red.

${ }^{10}$ Williams also applies the same argument to 'sincerity', the disposition to tell the truth. This, however, brings us beyond the limits of epistemic normativity and is problematic when applied to politics, as Williams $(2002,206)$ acknowledges.

${ }^{11}$ Someone might object that highlighting the benefits that accuracy provides can only support its instrumental value, not its intrinsic value (McGinn 2003). Yet Williams wants to push the seemingly paradoxical conclusion that truthfulness provides instrumental benefits only if pursued deontologically in all cases (Queloz 2018).

${ }^{12}$ Factual knowledge may also affect how we should act by correcting our views about the feasibility of an option. However, contemporary realists generally reject feasibility as the distinctive feature of realism (Sleat 2014b; Rossi 2019).
} 
2016, 253). What is given 'must be accepted as factual' (Frazer 2010, 495). That 'must' is an instance of epistemic normativity: it is the 'agent's receptivity to facts' (Philp 2012, $644)$ that is at stake, not her moral inclinations. An accurate epistemic reading of politics has enormous influence on a theory's ability to provide normative guidance because 'the weight, direction and relevance of different considerations would all systematically be altered by politics' constitutive features' (Jubb 2019, 362), and politics constrains the normative demands that can be placed on actors (Frazer 2006).

A second important way to capitalise on epistemic normativity in the political sphere is carried out by radical realists, who join realism to critical theory (Prinz and Rossi 2017). Epistemic normativity is a core notion in this tradition (for example, Rossi 2019, 2) which offers 'not a conceptual or moral argument, but an empirically-informed genealogical critique' (Rossi and Argenton 2020, 2).

Through genealogical analysis (Prinz and Raekstad 2020) - that is, a careful historical reconstruction of the genesis of a certain concept or practice - radical realists suggest that some moral intuitions might be ideological in character. For example, the instinctive distinction between the private and public spheres, which many share unreflectively, might be revealed to have had multiple meanings and implications throughout history (Geuss 2009). This does not mean that we should not use it at all, but it does mean that we ought to be cognisant of its variegated pedigree and meticulously specify its implications. Once this specification is done, what we end up with might be far less widely endorsed than the vague intuition we started with.

Radical realists do not preach against intuitions in every field, but specifically in political theory. The reason is that in political contexts, power warps individual thinking and adaptive preferences may obscure subjects' true interests (Geuss 1981). Ideology critique is thus political in character because the normative intuitions are often distorted by power or by political dynamics. In fact, either ideologies are the product of the operations of power or they play some hidden functional role in a society. Both should be probed by rational inquiry. ${ }^{13}$

The normative import of epistemic normativity, intended either as a conceptual argument about politics or as ideology critique, can also be criticised. In political contexts, epistemic normativity seems to operate mainly as a critical weapon. It is used to strike down normative obligations that would otherwise apply. It does not tell us where to go; it merely tells us that a direction others are pointing in has no merit. While negative criticism can still play an important normative role and even promote progressive change (Geuss 2014), it is necessarily more modest in its normative potential.

This criticism applies to both epistemic strategies deployed by realists. The epistemic argument about the conception of politics mainly operates in a negative way since it invalidates political theories that seriously misunderstand the context that they purport to regulate. Accordingly it works as a 'filter': it only admits normative judgements that are compatible with the matter of politics, while the others should be discarded (Sleat 2016).

Similarly, genealogies deployed by critical realists are mainly negative. They undermine normative intuitions that we think we share, and they debunk political theories that are

\footnotetext{
${ }_{13}$ As their name betrays, genealogical inquiries invite criticism as genealogical fallacies. In general, the history of how we came to believe something is not a reason against holding that belief. However, if causal history explicitly reveals that an intuition is tainted by somebody else's use of power, then we have reasons to mistrust it and seek independent justifications.
} 
insufficiently attentive to empirical analysis. To be fair, there are also (rare) vindicatory genealogies in realist thought - for example, Williams (2002) - but these are known to require more than epistemic normativity (Queloz 2018).

\section{A Joint Approach}

As we have seen, both normative sources have limitations. Instrumental normativity only requires coherence between attitudes and beliefs: one can hang on to false beliefs to preserve attitudes incompatible with reality. We may desire to completely expel power relations from political institutions, and accordingly we may imagine politics to be like a camping trip. Epistemic normativity, on the other hand, seems to mostly operate critically: it pushes us to accept the reality of worldly constraints, or it invalidates some normative consequences that theories provide. It can show us that politics is in fact nothing like a camping trip, but it doesn't tell us what we should do about it (beyond abandoning this false belief).

However, both limitations are mitigated once the two sources are taken together. Consider Williams's (1981a) famous example:

'The agent believes that this stuff is gin, when it is in fact petrol. He wants a gin and tonic. Has he reason, or a reason, to mix this stuff with tonic and drink it?' (102).

There is a sense in which the agent has an apparent reason to drink petrol and tonic. This reason is what provided him the motivation to do so: if we asked why he drank petrol, the answer would be that he thought it was gin. However, for Williams he has no real reason to drink petrol and tonic.

Williams (1981a) deploys this example to show a more interesting implication: that 'internal reason statements can be discovered' (104). In other words, once we filter our desires through an epistemically accurate view of the external world, we may discover new internal reasons about what we should do. If the agent has a desire to drink gin and tonic, once he accepts the truth that the bottle does not contain gin, he should conclude that he has no reason to drink it. Out of epistemic normativity, he should accept the empirical truth that the bottle contains petrol. Out of instrumental normativity, he should conclude that he has no reason to drink it. Moreover, when the agent learns a new truth, this might supply him additional reasons. For example, if the agent learns that the store downstairs sells his favourite gin, he might acquire a new reason to go out and buy it. As Williams (2005) notes elsewhere, such internal reason statements are not universally normative but 'normative for that agent' (11), for one that has the relevant goal (for example, one who wants to drink gin and tonic).

The combination of instrumental and epistemic normativities is key to understanding realist arguments about politics and their claimed autonomy from moral values. We offer three examples to illustrate this point. While they fall short of providing a full defence of realist normative recommendations, they can shed light on how instrumental and epistemic logics translate into realist political theories.

First, Machiavelli famously argued that political actors should learn to lie when necessary. While a politician should care for her reputation, if she categorically refuses to lie, she will never be successful. This political judgement is justified regardless of whether lying is morally forbidden and regardless of whether the politician's goal is morally justified. It stands on instrumental and epistemic normativities: instrumentally, political actors have 
(pro tanto) reasons to do what is conducive to their ends; and the facts of political competition tell us that the ability to lie is required to achieve any end.

Another realist classic that may serve as an example is Hobbes. According to him, the state's sovereign power is justified because it ensures individuals survive the state of nature's multiple threats. Once individuals acquire this true belief, they realise that complying with the sovereign's directives is instrumentally rational for all (Hobbes [1651] 2009). This normative strategy can be defined as 'true belief instrumentalism' - that is, the idea that 'any act is rational if it is one an individual would determine he should take to fulfil his present desires if he had true beliefs' (Hampton 1988, 36). ${ }^{14}$

The same instrumental and epistemic logic is also visible in Williams's theory of legitimacy, although his argument is more complex. Instrumentally, whatever normative ideals or material interests people have, they cannot be secured without politics. The political question is in fact a 'condition of solving, indeed posing, any others' (Williams 2005, 3). Epistemically, politics requires legitimacy because, in order to be stable, political institutions cannot rest exclusively on their ability to coerce, but they need to 'make sense' to people. People need to willingly believe in the institutions' right to coerce. For this reason, one needs to assess legitimate institutions positively. Moreover, whenever a regime makes sense to a citizen, this gives an internal reason to that person to comply with its commands. Thus, making sense is 'normative for that agent' (11).

Beyond the realist tradition, instrumental and epistemic reasons also have normative bite in real-world politics. Two examples can be offered to suggest this.

Take the case of a democratic politician representing a constituency with coal-based industries who is asked to vote on a green-economy bill. Let us assume that supporting the bill is the morally justified choice because it would heavily reduce the country's carbon emissions. It would do so by shutting down all coal-based power plants, where a meaningful number of people in the politician's district work. These people could be relocated without ending up on the streets, but the quality of their life would be severely affected. There is a moral sense in which the politician should vote in favour of the bill. And yet, there is also a rational sense in which she should protect her voters' interests instead.

Or take the international distribution of COVID-19 vaccines. Morally, it seems best to follow fully egalitarian principles of distribution across countries, taking particular consideration of those which lack the infrastructure to provide for their people. Yet, once we take notice of the realities of economic competition at the international level, and the harsh costs of lagging behind in reopening, it is easy to see how states have reason to prioritise their own citizens' health.

Obviously, these are merely examples and more work is needed to justify each of them. However, they importantly underscore that the problem is not merely that real political agents usually fail to comply with moral demands; rather, there is a sense in which they should also care about other things. Genuine conflicts between moral and nonmoral prescriptions constantly arise, and what realists claim is that morality does not, and should not, always carry the day. Accordingly, realism will always be morally unsatisfactory. But this is a feature, not a bug, of realism: the combination of instrumental and epistemic normativities should yield prescriptions that can conflict with our moral intuitions.

${ }^{14}$ See also the contractarian project (Gauthier 1986). An important difference is that contractarians sought to reduce morality to such epistemically enlightened instrumental rationality. Contrary to this reductivist intent, realism points out that the two normative sources may conflict. 


\section{Conclusions}

In a very influential book, Christine Korsgaard (1996) investigated different sources of normativity. Williams replied in the same book that Korsgaard seemed only interested in the sources of moral normativity. Yet it is far from uncontroversial that morality is all that's needed to answer the question 'What shall we do?' Elsewhere, Williams (1981b, 23) discusses the example of Paul Gauguin, who lived a morally abhorrent life; yet if he were to have done what morality required, we would have lost a valuable contribution to the arts. Williams (1981b) generalises this provocative intuition by stating that

'while we are sometimes guided by the notion that it would be the best of worlds in which morality were universally respected and all men were of a disposition to affirm it, we have, in fact, deep and persistent reasons to be grateful that that is not the world we have' (23).

Politics is a prominent candidate for a domain that cannot be exhausted by moral normativity. History should not blame Churchill for being a drunkard nor Kennedy for betraying his wife. Yet the study of other sources of normativity relevant to politics remains in its infancy.

In this article, we isolated two nonmoral sources of normativity which are often mentioned but rarely systematically treated (epistemic normativity and instrumental normativity), and we assessed their joint application to political contexts. Our conclusion is that while realism need not expunge morality from politics, and while it cannot claim that all normative judgements that are relevant for politics must be nonmoral, it does yield a richer picture of the normative justifications that should matter in political contexts.

Acknowledgements Earlier drafts of this paper have been presented at Università di Genova, and at the ECPR Joint Sessions Workshop on Political Normativity. We are particularly grateful to Zoltán Gábor Szücs and Ben Cross for detailed written notes, as well as to two anonymous referees for their insightful comments and challenges.

Funding Burelli: Funded by PRIN 2017 'Deceit and Self-Deception. How We Should Address Fake News and Other Cognitive Failures of the Democratic Public'. Destri: Funded by VoiCED - H2020-MSCA-IF-2018 European grant, project number 836571 .

\section{References}

Bagg S, Isak Tranvik (2019) An Adversarial Ethics for Campaigns and Elections. Perspect. Politics 17(4):973-987

Bartolini S (2018) The Political. ECPR Press, London; New York

Beardman S (2007) The Special Status of Instrumental Reasons. Philos Stud 134(2):255-287. https://doi. org/10.1007/s11098-005-8878-2

Beetz J, Pieter, Enzo Rossi (2017) The EU's Democratic Deficit in a Realist Key: Multilateral Governance, Popular Sovereignty and Critical Responsiveness. Transl Leg Theo 8(1):22-41. https://doi.org/10.108 0/20414005.2017.1307316

Bellamy R (2010) "Dirty Hands and Clean Gloves: Liberal Ideals and Real Politics." Eur J Polit Theo 9 (4)

Berlin I (2013) "The Originality of Machiavelli." In Against the Current: Essays in the History of Ideas, edited by Henry Hardy, 33-100. Princeton: Princeton University Press

BonJour L (1985) The Structure of Empirical Knowledge. Harvard University Press, Cambridge

Broome J (2005) Does Rationality Give Us Reasons? Philos iss 15:321-337

Burelli C (2019) "A Realistic Conception of Politics: Conflict, Order and Political Realism." Critical Review of International Social Political Philosophy, 1-23. https://doi.org/10.1080/13698230.2019.1604045 
Crisp R (2018) “Prudential and Moral Reasons.” The Oxford Handbook of Reasons and Normativity. June 7, 2018. https://doi.org/10.1093/oxfordhb/9780199657889.013.35

David M (2001) “Truth as the Epistemic Goal.” In Knowledge, Truth, and Duty, edited by M. Steup, 151-69. New York: Oxford University Press

David M (2013) "Truth as the Primary Epistemic Goal: A Working Hypothesis." In Contemporary Debates in Epistemology (Second Edition), edited by Steup M, John Turri, and Sosa E, 363-77. Wiley-Blackwell

Dovi S (2007) The Good Representative, vol 8. John Wiley \& Sons, Oxford

Elgin CZ (2004) True Enough. Philoso Issues 14:113-131

Elgin CZ (2017) True Enough. Cambridge, MA: MIT Press

Erman E, Niklas Möller (2015a) Why Political Realists Should Not Be Afraid of Moral Values. J Philos Res 40:459-464

Erman E, Niklas Möller (2015b) "Political Legitimacy in the Real Normative World: The Priority of Morality and the Autonomy of the Political." Br J Polit Sci 45 (1): 215-33. https://doi.org/10.1017/ S0007123413000148

Erman E, Niklas Möller (2018) "Political Legitimacy for Our World: Where Is Political Realism Going?" The J Polit 80 (2): 525-38

Erman E, Niklas Möller (2021) "Distinctively Political Normativity in Political Realism: Unattractive or Redundant." Ethical Theory Moral Pract, April. https://doi.org/10.1007/s10677-021-10182-8

Estlund D (2014) Utopophobia. Philos Public Aff 42(2):113-134. https://doi.org/10.1111/papa.12031

Frazer E (2006) Max Weber on Ethics and Politics. Politics Ethics Review 2(1):19-37

Frazer E (2010) "What's Real in Political Philosophy?" Contemp Political Theory 9 (4): 490

Freeden M (2012) Interpretative Realism and Prescriptive Realism. J Polit Ideol 17(1):1-11. https://doi.org/ 10.1080/13569317.2012.651883

Galston WA (2010) Realism in Political Theory. Eur J Polit Theo 9(4):385-411

Gauthier, David (1986) Morals by Agreement. Oxford University Press http://books.google.it/ books?hl=it\&lr=\&id=rH_h_Pb28_oC\&oi=fnd\&pg=PR7\&dq=gauthier +hobbes+moral+theorist\&ots=

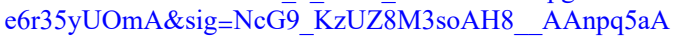

Geuss R (1981) The Idea of a Critical Theory: Habermas and the Frankfurt School. Cambridge University Press, Cambridge

Geuss R (2008) Philosophy and Real Politics. Princeton: Princeton University Press

Geuss R (2009) Public Goods, Private Goods. Princeton University Press

Geuss R (2014) "Must Criticism Be Constructive?” In A World Without Why, edited by Geuss R, 68-90. Princeton: Princeton University Press

Goldman AI (1999) Knowledge in a Social World. New York: Oxford University Press, Oxford

Goldman AI (2002) Pathways to Knowledge: Private and Public. Oxford; New York: Oxford University Press

Hall E (2015) Bernard Williams and the Basic Legitimation Demand: A Defence. Polit Stud 63(2):466-480. https://doi.org/10.1111/1467-9248.12070

Hampton J (1988) Hobbes and the Social Contract Tradition. Cambridge University Press

Hobbes T (1651) 2009. Leviathan. Edited by J. C. A. Gaskin. Reissue edition. Oxford; New York: Oxford University Press

Honig B (1993) Political Theory and the Displacement of Politics. Cornell University Press, New York

Horton J (2010) Realism, Liberal Moralism and a Political Theory of Modus Vivendi. Eur J Politi Theo 9(4):431-448. https://doi.org/10.1177/1474885110374004

Horton J (2017) “What Might It Mean for Political Theory to Be More 'Realistic'?” Philosophia 45 (2): 487-501. https://doi.org/10.1007/s11406-016-9799-3

Hume D (1978) An Enquiry Concerning the Principles of Morals, 2nd edn. Selby-Bigge, Oxford

Jubb R (2015) The Real Value of Equality. The J Polit 77(3):679-691. https://doi.org/10.1086/681262

Jubb R (2019) “On What a Distinctively Political Normativity Is.” Political Studies Review 17 (4): 360-69

Kant I (1998) Groundwork of the Metaphysics of Morals. Edited by Mary J. Gregor. Cambridge Texts in the History of Philosophy. Cambridge: Cambridge University Press

Kiesewetter B (2015) Instrumental Normativity: In Defense of the Transmission Principle. Ethics 125(4):921946. https://doi.org/10.1086/680911

Kolodny N (2005) Why Be Rational. Mind 114(455):509-563. https://doi.org/10.1093/mind/fzi509

Korsgaard CM (1996) The Sources of Normativity. Second Edition edizione. Cambridge; New York: Cambridge University Press

Leader Maynard J (2021) "Political Realism as Methods Not Metaethics." Ethical Theo Moral Pract, April. https://doi.org/10.1007/s10677-021-10183-7

Leader, Maynard, Jonathan, and Alex Worsnip (2018) Is There a Distinctively Political Normativity? Ethics 128(4):756-787. https://doi.org/10.1086/697449 
Machiavelli N (1532) 2010 The Prince. Translated by Harvey Mansfield. Chicago: University of Chicago Press

McCormick JP (2020) Reading Machiavelli: Scandalous Books, Suspect Engagements, and the Virtue of Populist Politics. Princeton University Press, Princeton

McGinn C (2003) "Isn't It the Truth?” The New York Review of Books L (6)

Morgenthau HJ (2005) Politics Among Nations. Edited by Kenneth W. Thompson and David Clinton. 7 edition. Boston: McGraw-Hill Higher Education

Nawar T (2019) "Veritism Refuted? Understanding, Idealization, and the Facts." Synthese, October. https:// doi.org/10.1007/s11229-019-02342-2

Newey G (1997) Metaphysics Postponed: Liberalism, Pluralism, and Neutrality. Polit Stud 45(2):296-311. https://doi.org/10.1111/1467-9248.00082

Newey G (2000) After Politics: The Rejection of Politics in Contemporary Liberal Philosophy. Springer

Nozick R (1974) Anarchy, State, and Utopia. Blackwell: Oxford

Nye S (2015) 'Real Politics and Metaethical Baggage'. Ethic Theory Moral Prac 18(5):1083-1100.

Philp M (2010) What Is to Be Done? Political Theory and Political Realism. Eur J Polit Theo 9(4):466-484. https://doi.org/10.1177/1474885110374010

Philp M (2012) "Realism without Illusions." Polit Theo 40 (5): 629-49. https://doi. org/10.1177/0090591712451723

Piller C (2009) Desiring the Truth and Nothing but the Truth. Nô̂s 43(2):193-213

Prinz J, Paul Raekstad (2020) The Value of Genealogies for Political Philosophy. Inquiry 0(0):1-20. https:// doi.org/10.1080/0020174X.2020.1762729

Prinz J, Enzo Rossi (2017) Political Realism as Ideology Critique. Crit Rev Int Soc Polit Philos 20(3):348365. https://doi.org/10.1080/13698230.2017.1293908

Queloz M (2018) Williams's Pragmatic Genealogy and Self-Effacing Functionality. Philos Impr 18(17):1-20

Rawls J (1971) A Theory of Justice. Harvard University Press, Cambridge

Raz J (2005) The Myth of Instrumental Rationality. J Ethics Soc Philos 1:1

Rossi E (2016) Can Realism Move Beyond a Methodenstreit? Politi Theo 44(3):410-420. https://doi. org/10.1177/0090591715621507

Rossi E (2019) "Being Realistic and Demanding the Impossible." Constellations, 2019. https://doi. org/10.1111/1467-8675.12446

Rossi E, Carlo Argenton (2020) “Property, Legitimacy, Ideology: A Reality Check.” The J Polit, July. https:// doi.org/10.1086/710781

Sandel MJ (1998) Liberalism and the Limits of Justice. Cambridge University Press, Cambridge

Schmidtz D (2016) A Realistic Political Ideal. Soc Philos Policy 33(1-2):1-10. https://doi.org/10.1017/ S0265052516000406

Schroeder M (2004) The Scope of Instrumental Reason. Philos Perspect 18(1):337-364. https://doi. org/10.1111/j.1520-8583.2004.00032.x

Schroeder M (2007) Slaves of the Passions. Oxford; New York: Oxford University Press

Schroeder M (2009) "Means-End Coherence, Stringency, and Subjective Reasons." Philos Stud 143 (2): 223-48. https://doi.org/10.1007/s11098-008-9200-x

Setiya K (2007) Cognitivism About Instrumental Reason. Ethics 117(4):649-673. https://doi. org/10.1086/518954

Sleat M (2013) Liberal Realism: A Realist Theory of Liberal Politics. Manchester University Press, Manchester

Sleat M (2014a) "Legitimacy in Realist Thought: Between Moralism and Realpolitik." Politi Theo 42 (3): 314-37

Sleat M (2014b) "Realism, Liberalism and Non-Ideal Theory Or, Are There Two Ways to Do Realistic Political Theory?" Politi Stud 64 (1): 27-41. https://doi.org/10.1111/1467-9248.12152

Sleat M (2016) "What Is a Political Value? Political Philosophy and Fidelity to Reality." Soc Philos Policy 33 (1-2): 252-72. https://doi.org/10.1017/S0265052516000285

Southwood N (2008) Vindicating the Normativity of Rationality. Ethics 119(1):9-30. https://doi. org/10.1086/592586

Waldron J (1999) Law and Disagreement. Oxford University Press, Oxford; New York

Waldron J (2013) “Political Political Theory: An Inaugural Lecture.” J Polit Philos 21 (1): 1-23. https://doi. org/10.1111/jopp.12007

Waltz KN (2001) Man, the State, and War: A Theoretical Analysis. Columbia University Press, New York

Walzer M (2004) "Emergency Ethics.” In Arguing About War, by Michael Walzer, 33-50. New Haven: Yale University Press

Weber M (1919) 2004 The Vocation Lectures: "Science as a Vocation" \& "Politics as a Vocation." Edited by David Owen and Tracy B. Strong. Translated by Rodney Livingstone. Indianapolis: Hackett Publishing $\mathrm{Co}$ 
Wedgwood R (2002) The Aim of Belief. Philos Perspect 16:267-297

Williams B (1973) 'A Critique of Utilitarianism'. In: Utilitarianism: For and Against, edited by J. J. C. Smart and Bernard Williams. Cambridge University Press, Cambridge

Williams B (1981a) “Internal and External Reasons”. In: Moral Luck: Philosophical Papers 1973-1980. Cambridge University Press, Cambridge, pp 101-113

Williams B (1981b) “Moral Luck.” In Moral Luck: Philosophical Papers 1973-1980, 20-39. Cambridge: Cambridge University Press

Williams B (2002) Truth and Truthfulness: An Essay in Genealogy. Princeton: Princeton University Press

Williams B (2005) "Realism and Moralism in Political Theory." In In the Beginning Was the Deed: Realism and Moralism in Political Argument, edited by Geoffrey Hawthorn, 1-17. Princeton: Princeton University Press.

Publisher's Note Springer Nature remains neutral with regard to jurisdictional claims in published maps and institutional affiliations. 